\title{
Annual study of airborne pollen in Mexicali, Baja California, Mexico
}

\author{
S. Ahumada-Valdez, M. Quintero-Nuñez, O. R. García-Cueto \\ \& R. Venegas \\ Engineering Institute, Air Quality Department, \\ Autonomous University of Baja California, Mexico
}

\begin{abstract}
The purpose of the study is to present a preliminary survey of the presence of airborne pollen in the air of Mexicali, and to record the most common pollen particles present in its atmosphere. Samples were collected using Rotorod model 40, every 24 hours. The quantitative parameters measured were: diversity, richness, volume, and frequency, as well as its relation with meteorological factors, like average temperature, relative humidity average, and precipitation. The airborne pollen concentration was estimated as 1,973 grains $/ \mathrm{m}^{3}$ and 72 taxon pollen were detected outstanding March with 30 pollen types that correspond to $41.6 \%$ of the total detected. The pollen types were grouped according to their phenology. In spring a total of 44 types were classified (61\%), for summer 23 types were listed (32\%); in autumn 40 types appeared (55\%), during the winter were identified 39 types (54\%). Respect the shrubs 63 grains $/ \mathrm{m}^{3}$ was observed in August representing the 24.9\%, all equivalent to $3.19 \%$ of the annual total. In relation to the weeds, were better observed in September with 295 grains $/ \mathrm{m}^{3}$, representing $30.87 \%$ of this group, equivalent to $14.95 \%$, of the annual total. The most abundant group with greater biological diversity was the trees with a bulk that fluctuated between 103 to 146 grains $/ \mathrm{m}^{3}$ and richness identified with 32 pollen types. The Pearson correlation analysis demonstrated pollen grains do not have a significant linear association with the mean monthly temperature, but they have it, with the maximum relative humidity.
\end{abstract}

Keywords: aerobiological survey, airborne pollen, allergenic particles, Mexicali. 


\section{Introduction}

Nowadays aeropalinologycal studies are of great importance at worldwide level, they give us the opportunity to develop in many areas and topics, such a climate change, archaeology and health, they contribute whit valuable data related with taxonomic spectrum of pollen in the atmosphere of different regions in the world (Kobzar [1]; Detandt and Nolard [2]; Gehrig and Peeters [3]; Rodriguez-Rajo et al. [4]). These studies have allowed one to establish the relation with meteorological parameters and have helped to develop dispersion models, that have been helpful in the diagnosis of health problems in respiratory tract (D'Amato et al. [5]; Trivi et al. [6]; Schueler and Schlunzen [7]; Egger et al. [8]; Assing et al. [9]). There is information about pollen with allergenic characteristics affecting the quality of life of sensitive people; the pollen particles are suspended in the atmosphere, therefore they are considered as part of the atmospheric pollutants and the diagnostic of respiratory diseases (GonzalezLozano et al. [10]). A few studies have been realized in some regions around Mexico (Bronillet [11]), as well as studies related with the behavior of particles suspended in the atmosphere for different zones in Mexico city (Montes and Cisneros [12]; Ramirez and Rodriguez [13]; Cid del Prado [14]; Rosas et al. [15]; Gonzalez-Lozano et al. [10]); unfortunately for the city of Mexicali, BC, Mexico, there are not records for this kind of aerobiological analyses, being a city where the levels of atmospheric contamination have violated the permitted air quality many times (Reyna and Arriola [16]).

The palinologycs studies allow us to know the types, dominance, and behavior of pollen and its relation with some meteorological parameters. These studies could be also considered as a useful tool for the health sector to allow identify causal agents in patients with allergic problems, as well as the implementation of preventive measures for this kind of diseases in the respiratory tract (Riggioni et al. [17]; Ferreiro et al. [18]; Subiza [19]; Mandrioli and De Nuntiis [20]).

\section{Materials and methodology}

This study was performed in the city of Mexicali, B. C., Mex., located in northwest of Mexico with geographical coordinates North Latitude $32^{\circ} 40^{\prime}$, West longitude $115^{\circ} 28^{\prime}$, (Figure 1) in the Subprovince of the Low Delta of the Colorado River belonging to the Great Physiographic Province of the Sonoran Desert, (Shreve and Wiggins [21]). Its basic characteristics, is almost flat area, expose to flood, conformed by very fine sediments like clays and silts (Venegas [22]). Most of the time these particles under certain atmospheric conditions remain suspended in the air, contributing to the atmospheric pollution. The climate conditions, warm and dry summer, winter rain regime, and mean annual precipitation slightly greater to $70 \mathrm{~mm}$, wind direction in winter is NW$\mathrm{SE}$ and summer the dominant wind is S-SE; the mean annual temperature is $22.4^{\circ} \mathrm{C}$ with extreme annual variations, during the summer the maximum 
temperature reach $50^{\circ} \mathrm{C}$ and in the winter the minimum can be lower than $0^{\circ} \mathrm{C}$ (García [23]).

The city has been built over the Delta Colorado river, it allows an intensive agricultural activity; in fact, two immense agricultural valleys surround the city; to the north the Imperial Valley, in the state of California in the United States of North America and to the south, the Mexicali Valley in the state of Baja California, Mexico, fig. 1.

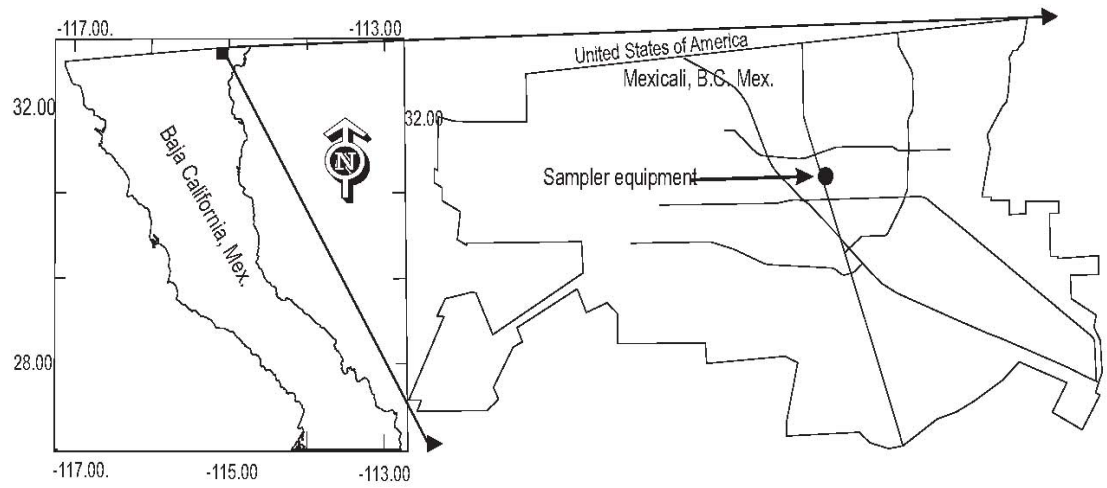

Figure 1: $\quad$ Localization of study area.

The farming activity in the Mexicali valley has two agricultural cycles, during spring-summer, the main ones are: cotton, sorghum, and corn; and during the autumn-winter: wheat, barley, safflower, and green onion. The total surface under irrigation in the Mexicali valley is 165.121 .00 hectares.

In relation to the urban landscape, Venegas [24] identified 47 species of trees and shrubs the most common species used for landscaping. Only five of these, are regional or natives: Populus fremontii (fremont cottonwood), Prosopis juliflora (Mesquite), Washingtonia robusta (Mexican fan palm) and Washingtonia filifera, (California fan palm) Atriplex lentiformis (big saltbush). The majority of the species are considered non natives, they come mainly from tropical and subtropical ecosystems, like: Bougainvillea spectabilis (great bougainvillea), Caesalpinia gilliesii (bird of paradise), Callistemon citrinus and C. viminalis (lemon bottlebrush), Casuarina equisitifolia (she-oak, horsetail), Eucalyptus camaldulensis (river red gum), Ficus benjamina (Benjamin tree), Ficus microcarpa (Indian Laurel), Jacaranda mimosifolia (jacaranda), Melia azederach (chinaberry), Morus nigra (black mulberry), Nerium oleander (rose bay), Phoenix dactilifera (Date palm trees), Pluchea sericea (arrowweed).

The airborne pollen samples were collected using Rotorod model 40 equipment, with rotation and impact of particles in pre-lubricated rods, obtaining two simultaneous and equal samples (Frenz and Guthrie [25]). The equipment was installed on the roof of the Engineering Institute of the Baja California University (UABC), fifteen meters above ground, geography coordinates $32^{\circ} 37^{\prime}$ $52^{\prime \prime} \mathrm{N}, 115^{\circ} 26^{\prime} 41.4^{\prime \prime} \mathrm{W}$. 
The standard parameters for identification and quantification of pollen grains were adjustments to obtain sampling at $5 \%$ instead of $10 \%$, as a result the volume of air sampling was $1,56 \mathrm{~m}^{3}$ per period of sampling (Elander [26]). The collected samples were stained with solution of Calberla's, consisting of basic preparation of fuchsine solution, widely used for pollen identification under microscope.

Samples were collected every 24 hours, five days a week, according to the standard method (Brown [27]). The grains of pollen were identified following the criteria of Grant et al. [28], most of them at taxonomic level of Family, Genus and Species.

The identified airborne pollen types were grouped according to their biological form in trees, shrubs, and weeds. In the last group were included the grasses, herbaceous and all the plants that compete with the cultured species. The quantitative parameters used to measure the types of pollen were their diversity, richness, volume, and frequency, as well as its relation with meteorological factors, like mean temperature, relative humidity average and precipitation. To analyze the relationship between pollen data and meteorological variables, the Pearson correlation was used to determine the level of significance of each correlation. The analysis was made for all the period of capture with program Statistica V6.0.

\section{Results}

A total of 1,973 grains $/ \mathrm{m}^{3}$ of airborne pollen concentration (TP) were identified with a richness of 72 types of pollen during the year, fig. 2 .

In relation to the richness, the months from January to June had a similar behavior with an average of 24 airborne pollen monthly; outstanding March with

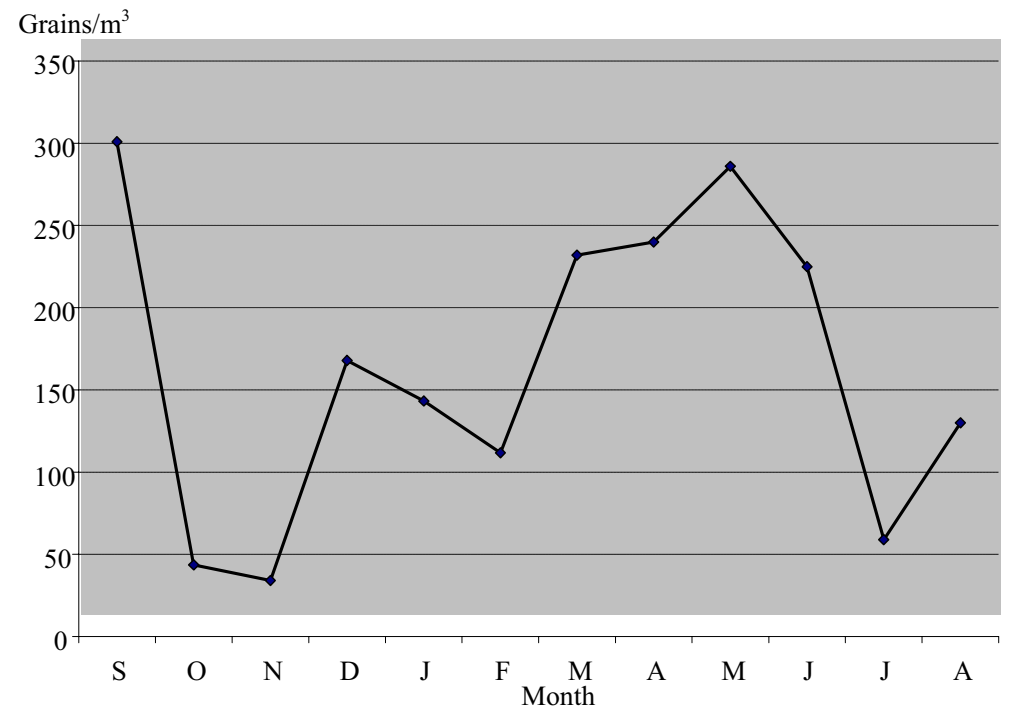

Figure 2: Annual pollen distribution. 


\section{Grains $/ \mathrm{m}^{3}$}

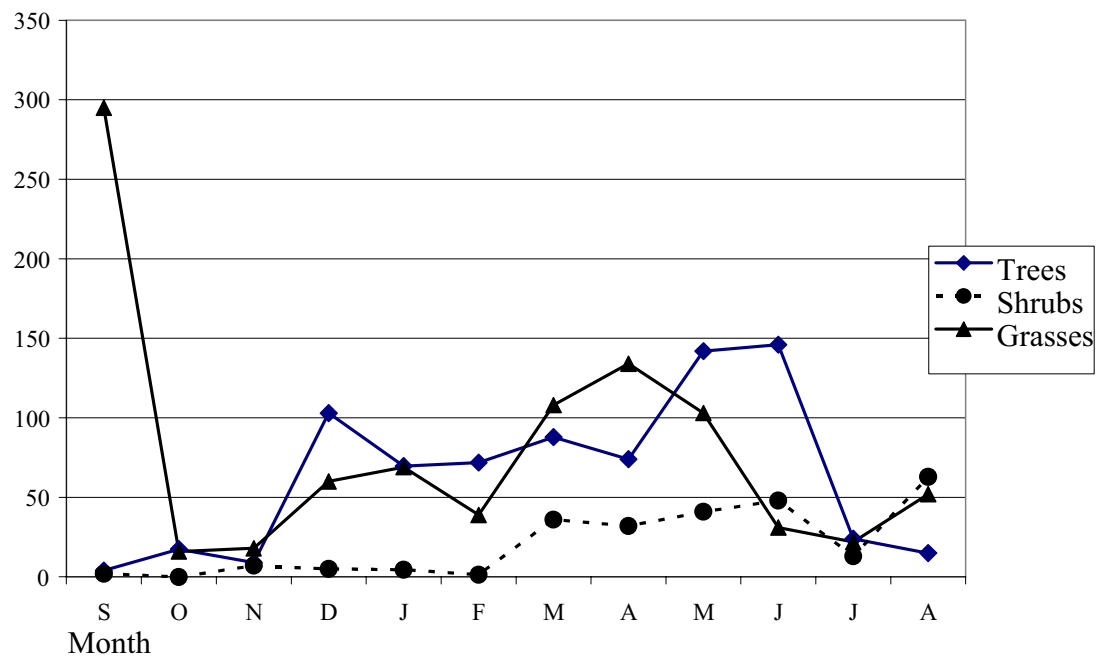

Figure 3: $\quad$ Trees, shrubs, grasses.

30 pollen types that correspond to $41.6 \%$ of the total identified for all the sampling year.

According to distribution by life forms, figure 3 shows its behavior during the sampling period.

Trees have the highest values from December to June; months of May and June outstanding 142 and 146 grains $/ \mathrm{m}^{3}$ respectively, these two months represent each one, the $18.58 \%$ and the $19.10 \%$ for this group of plants, and $7.2 \%$ and $7.40 \%$ for the same period in relation to the annual total.

Respect the shrubs the relevant data with 63 grains $/ \mathrm{m}^{3}$ is observed in August representing the $24.9 \%$ for this form of life, all equivalent to $3.19 \%$ of the annual total. In relation to all the plants that were included within the group of the weeds, relevant data is observed in the months of March 108 grains $/ \mathrm{m}^{3}$, April 134 grains $/ \mathrm{m}^{3}$, May 103 grains $/ \mathrm{m}^{3}$ and September with 295 grains $/ \mathrm{m}^{3}$, representing each month the $10.77 \%, 14 \%, 11.30 \%$, and $30.87 \%$ respectively of this group of plants, equivalent to $5.22 \%, 6.8 \%, 5.47 \%$, and $14.95 \%$, of the annual total.

Within the weeds group all herbaceous are included, weeds that compete with the cultivated plants and plants used for landscaping in the city and private gardens. In this group the species belonging to the Poaceae Family represent the greater volume of pollen collected, but due to the difficulty of identifying them at taxonomic level of genus and specie, most of these are reported at taxa family; the distribution during the four seasons in the year is shown in table 1.

Trees prevail in all the four seasons; in spring season a total of 44 types were identified, prevailing Castanea sativa with 172 grains $/ \mathrm{m}^{3}$; for summer season 
23 types were identified; in autumn 40 types appeared, prevailing genus Casia with 83 grains $/ \mathrm{m}^{3}$, during the winter were identified 39 types, with the family Poaceae showing dominance in volume with 102.23 grains $/ \mathrm{m}^{3}$.

Table 1: $\quad$ Types and volume.

\begin{tabular}{lllllll}
\hline & Trees & Types & Shrubs & Types & Grass & Types \\
& & & & & & \\
\hline Spring & 362 & 44 & 121 & 9 & 268 & 13 \\
Summer & 43 & 23 & 78 & 6 & 369 & 7 \\
Autumn & 129.5 & 40 & 12 & 10 & 94 & 13 \\
Winter & 228.62 & 39 & 41.8 & 5 & 216 & 16 \\
\hline
\end{tabular}

\section{Discussion and conclusions}

The density of pollen particles of families Chenopodaceae-Amarataceae during sampling months fluctuated between 1-362 grains $/ \mathrm{m}^{3}$; the greater volume was counted in September, which means that this month could be the one with greater production of pollen, but also is observed that it could be transported by winds NE-NW; other significant peaks with greater concentrations are for March, April, May and June with a mean of 245.75 grains $/ \mathrm{m}^{3}$, representing $12.46 \%$ of the annual total. Also from March to June, the greater velocity of wind coming from the NW was registered with an average of $2.05 \mathrm{~m} / \mathrm{s}$ (personal communication García-Cueto [29]).

The meteorological conditions in Mexicali do not adjust to the four season characteristics; consequently the sampling period was divided in two stages (García-Cueto et al. [30]), warm season from April to September, and the cold one from October to March, tables 2 and 3. The monthly presence of pollen grains $/ \mathrm{m}^{3}$ does not have a correlation with the temperature, rainfall and the wind velocity. For July and August, the wind blow trend did not follow defined pattern for regular behavior S-SE, in the summer season.

March appears as the month with a great diversity, with 30 airborne pollen types; this matches the beginning of the flowering in spring, outstanding pollen pertaining to the Family Poaceae and the Genus Ambrosia. The presence of the Family Poaceae throughout the year and periods with greater abundance,

Table 2: $\quad$ Pollen in warm season.

\begin{tabular}{lllllll}
\hline Month & A & M & J & J & A & S \\
\hline Grains $/ \mathrm{m}^{3}$ & 240 & 286 & 225 & 59 & 130 & 301 \\
$\mathrm{~T}^{\circ} \mathrm{C}$ & 23.6 & 28.8 & 32.5 & 37.2 & 35.5 & 29.3 \\
$\% \mathrm{HR}$ & 28.9 & 30.9 & 29.3 & 34.2 & 42.4 & 32.9 \\
$\mathrm{PP} \mathrm{mm}$ & 10.8 & 0 & 0 & 0 & 43 & 0 \\
Wind m/s & 2.2 & 1.8 & 2.2 & 1.8 & 1.8 & 1.9 \\
Wind & $\mathrm{NW}$ & $\mathrm{N}$ & $\mathrm{N}, \mathrm{NE}$ & $\mathrm{N}$ & $\mathrm{NW}$ & $\mathrm{SE}$ \\
direction & & & & & & \\
\hline
\end{tabular}


Table 3: $\quad$ Pollen in cold season.

\begin{tabular}{lllllll}
\hline Month & $\mathrm{O}$ & $\mathrm{N}$ & $\mathrm{D}$ & $\mathrm{J}$ & $\mathrm{F}$ & $\mathrm{M}$ \\
\hline Grains $/ \mathrm{m}^{3}$ & 44 & 34 & 168 & 143 & 112 & 232 \\
$\mathrm{~T}^{\circ} \mathrm{C}$ & 24.5 & 17.1 & 15 & 15.9 & 16.6 & 20.8 \\
$\% \mathrm{HR}$ & 42.6 & 49 & 52.5 & 62.1 & 63.6 & 37.8 \\
$\mathrm{PP} \mathrm{mm}$ & 26.5 & 13 & 8.75 & 27.7 & 22.5 & 10 \\
Wind m/s & 1.4 & 1.2 & 1.1 & 1.3 & 1.4 & 2 \\
Wind & $\mathrm{NW}$ & $\mathrm{NW}$ & $\mathrm{NW}$ & $\mathrm{NW}$ & $\mathrm{N}$ & $\mathrm{NW}$ \\
direction & & & & & & \\
\hline
\end{tabular}

concords with the agricultural cycles of the region, for example cycle autumnwinter sowing wheat, safflower, barley, and Rye grass. Cycle spring-summer sowing forage sorghum and corn; in addition to perennial cultured like the Bermuda grass.

The most abundant group with greater biological diversity was the trees with a bulk that fluctuated between 103 to 146 grains $/ \mathrm{m}^{3}$ and richness identified with 32 airborne pollen. In this plants group were identified pollen with allergenic characteristics according to the Department of Health Sciences of the University of Arizona, among them appear the Genus: Washingtonia, Tamarix, Platanus, Quercus, Fraxinus, Ulmus, Juniperus, Populus, Ligustrum and Juglans (Shumacher [31]).

Respect to the weeds group, they were also pollen with allergenic characteristics, like Genus Ambrosia, Amaranthus, Chenopodium, Artemisia (Shumacher [31]). In the Chenopodiacea-Amarantacea group the greater volume happens in September with 362.1 grains $/ \mathrm{m}^{3}$, the mean temperature for the month was $29.3^{\circ} \mathrm{C}$, and it seems not to be influence by the environmental suspension and dispersion of particles, the mean relative humidity for this month was of $32.9 \%$ that could have favored the suspended particles. The Family Poaceae included densities that fluctuate between three and eighty grains $/ \mathrm{m}^{3}$, the richness consisted of nine types detected, and among them is Sorghum halepense as allergenic pollen (Shumacher [31]).

In relation to the months with highest relative humidity were December, January and February, with $52.4 \%, 60.6 .1 \%$ and $63.4 \%$, respectively, being observed an agreed relation with the volume of pollen; the same happens in relation to the average temperature.

Table 4 shows the results of the statistical analysis between meteorological variables and the presence or absence of pollen. The data correspond to monthly averages, the correlation of Pearson where $\mathrm{R}^{2}$ is the coefficient of determination and $\mathrm{R}$ is the correlation coefficient, $\mathrm{P}$ is the significance associated to the value of $\mathrm{R}$, whereas HRMX is maximum relative humidity; HRMN, minimum relative humidity; HRMED, mean relative humidity; TMAX, maximum temperature; TMED, minimum temperature; and PREC, pluvial precipitation.

This analysis show that the correlation coefficient between pollen and mean temperature, was low and non-significant $\mathrm{R}=0.13, \mathrm{P}=0.22$. The relationship between pollen and maximum relative humidity showed a better correlation in 
Table 4: $\quad$ Pearson correlation.

\begin{tabular}{lll}
\hline Climatic variables & $\left(\mathrm{R}^{2}\right)$ & $(\mathrm{R})$ \\
\hline HRMX & 0.3375 & 0.58 \\
HRMN & 0.1944 & 0.44 \\
HRMD & 0.2702 & 0.52 \\
TMAX & 0.024 & 0.15 \\
TMIN & 0.0089 & 0.09 \\
TMED & 0.0164 & 0.13 \\
PREC & 0.2182 & 0.47 \\
TMED- HRMAX & 0.36 & 0.60 \\
\hline
\end{tabular}

relation to the previous, $\mathrm{R}=0.58, \mathrm{P}=0.001$; it means the coefficient indicates that the volume of pollen is directly proportional with the maximum values of relative humidity. Oliveira et al. [33] found positive correlation with relative humidity, Boral and Bhattacharya [34] found the same positive relation between meteorology variables like relative humidity, temperature and precipitation.

When the inclusion of an additional variable is made (mean temperaturemaximum relative humidity), and it correlates with the temperature average and maximum relative humidity, $\mathrm{R}$ was considered $=0.60$, whose result also is significant, which was the best one of the coefficients of found correlation; this means that the value of pollen can be explained up to a $36 \%$ according to the coefficient of determination $\left(\mathrm{R}^{2}\right)$ estimated.

Finally this first aerobiological study in the region provides interesting results with the meteorological variables, and its possible relation of species identified as allergenic. These results demonstrate the importance of continuing with this kind of aerobiology studies, to develop a pollen map of the region that could contribute to recognize the airborne allergenic particles and their influence in the individuals.

\section{References}

[1] Kobzar, V.N., Aeropalynological monitoring in Bishkek, Kyrgyzstan. Aerobiologia 15, pp. 149-153, 1999.

[2] Detandt, M., \& Nolard, N., The fluctuations of the allergenic pollen content of the air in Brussels (1982 to 1997). Aerobiologia 16, pp. 55-61, 2000 .

[3] Gehrig, R., \& Peeters, A.G., Pollen distribution at elevations above 1000 $\mathrm{m}$ in Switzerland. Aerobiologia 16, pp. 69-74, 2000.

[4] Rodríguez-Rajo, Seijo, M.C., \& Jato, V., Estudio aerobiológico de la atmósfera de A Guardia, NO de España. REA 7, pp. 7-15, 2002.

[5] D’Amato, G., Liccardi, G., \& Frenguelli, G., Thunderstorm-asthma and pollen allergy. Allergy 62, pp.11-16, 2007.

[6] Trivi de Mondri, M. E., Burry, L.S., \& D’Antoni H.L., Dispersióndepositación del polen actual en la Tierra del Fuego, Argentina. Revista Mexicana de Biodiversidad 77, pp. 89-95, 2006. 
[7] Schueler, S., H.L. \& Schlunzen K., Modeling of oak pollen dispersal on the landscape level with a mesoscale atmospheric model. Environmental Modeling and Assessment, 11(3), pp. 179-194, 2006.

[8] Egger, M., Mutschlechner, S., Wopfner, N., Gadermaier, G., Briza, P., \& Ferreira F., Allergy 61, pp. 461-476, 2006.

[9] Assing, K., Bodtger U., \& Poulsen, L. K., Seasonal dynamics of chemokine receptors and CD62L in subjects with asymptomatic skin sensitization to birch and grass pollen. Allergy 61 (6), pp.759-768,2006.

[10] González-Lozano, C., Cerezo-Moreno, A., González-Macías, C. \& Salazar, C.L., Comportamiento de las partículas suspendidas y polen en la atmósfera de la región norte de la Zona Metropolitana de la Ciudad de México. Revista de la Sociedad Química de México, 43(5), pp. 155-164, 1999.

[11] Bronillet, T. I., An annual study of airborne in northern Mexico City. Aerobiologia 12, pp. 191-195, 1996.

[12] Montes, J., \& Cisneros, P., Los polenes atmosfericos de la ciudad de Mexico. Alergia. 29(2) pp. 51-60, 1982.

[13] Ramírez, O., \& Rodríguez, B., Estudio ilustrado de los pólenes del aire de México. Alergia 3, pp. 187-217. México, 1961.

[14] Cid del Prado, L., Lluvia de Polen de la Ciudad de Toluca. Revista de la Facultad de Medicina, Universidad Autónoma del Estado de México. 2(1), pp. 28-31, 1992.

[15] Rosas, I., Calderon, C., Ulloa, M., \& Lacey, J., Abundance of airborne Penicillium CFU in relation to urbanization in Mexico City. Applied and environmental Microbiology. Aug., pp. 2648-2652, 1993.

[16] Reyna, C.M., \& Arriola Z. H., Contaminación y medio ambiente en Baja California (Capítulo 6). El estudio de las principales enfermedades respiratorias y los contaminantes del aire en Mexicali, Baja California, ed. Porrua: México, pp.137-155, 2006.

[17] Riggioni, O., Montiel, M., Fonseca, J., Jaramillo, O., Carvajal, E., Rosencwaig, P., \& Colmenares A., Los pólenes de gramíneas y su relación con manifestaciones alérgicas en Costa Rica. Rev. Biol. Trop., 42(I Supl.), pp. 41-45, 1994.

[18] Ferreiro, A., Núñez, O., Rico, D., Soto, M., \& López, R., Pólenes alergénicos y polinosis en el área de La Coruña. Revista Española de Alergología e Inmunología Clínica 13(2) pp. 98- 101, 1998.

[19] Subiza J., Cómo interpretar los recuentos de pólenes. Alergología e Inmunología Clínica. 16, pp. 59-61, 2001.

[20] Mandrioli, P., \& De Nuntiis, P., Forecasting tools for pollinosis: Aerobiology and Allergens. Allergy 57(s73), pp. 277, 2002.

[21] Shreve, F.\& Wiggins, I.L., Vegetation and Flora of Sonoran Desert. Volume 1, Stanford University Press. Stanford California: USA, 1964.

[22] Venegas, F. R., Physical and Biological Features of the Colorado River. The U.S.-Mexican border environment: Lining the All-American Canal: Competition or Cooperation for Water in the U.S.-Mexican Border 
COLEF-SCERP Monograph Series, Vicente Sanchez Munguía: Mexico, pp. 1-19 2006.

[23] García, E., Modificaciones al sistema de clasificación climática de Köppen, (Para adaptarlo a la República Mexicana). Instituto de Geografía, UNAM. pp. 250, 1981.

[24] Venegas F. R., Manual para el reconocimiento de los árboles y arbustos más comunes en la ciudad de Mexicali. UABC: México, 1991.

[25] Frenz, D., \& Guthrie, B.L., A rapid, reproducible method for coating Rotorod Sampler collector rods with silicone grease, Annals of Allergy, Asthma \& Immunology, 87, pp. 390- 393, 2001.

[26] Elander, J, Volumetric Calculations. Sampling Technologies, Multidata LLC, 2000.

[27] Brown, T., Frenz, D.A., \&.Wimpsett, T. L., Operating Instructions for the Rotorod Sampler. Sampling Technologies, Inc., Minnetonka, 1993.

[28] Grant, S.E., Choice and use of equipment (Chapter 2). Sampling and Identifying Allergenic Pollen and Molds, ed. Blewstone Press: San Antonio Texas, pp. 7-13, 2000.

[29] García-Cueto O. R. Personal Communications, 20 July 2007, Head of Meteorology Department, Engineering Institute, UABC, Mexico

[30] García-Cueto, O.R., Martínez, C.A., Cervantes, P.J. \& Tejeda N. D., Evaluación del bioclima humano en Mexicali, B. C. y su comparación con otras ciudades cálidas de la Republica Mexicana. Reporte técnico, Instituto de Ingeniería, UABC, 1996.

[31] Allergy and Asthma in the southwestern Unites States. Web site, Arizona, USA http;//allergy. peds.arizona.edu/southwest/trees_shrubs, content owner Schumacher, M. J., 2007.

[32] Allergy and Asthma in the southwestern Unites States. Web site, Arizona, USA http://allergy. peds.arizona.edu/southwest/weeds, content owner Schumacher, M. J., 2007.

[33] Oliveira, M., Ribeiro H., \& Abreu, I., Annual variation of fungal spores in atmosphere of Oporto: 2003. Ann Agric Environ Med. 12, pp. 309-315, 2005.

[34] Boral, D., \& Bhattacharya, K., Aerobiology, allergenicity and biochemistry of three pollen types in Berhampore town of West Bengal, India. Aerobiologia 16, pp. 417-422, 2000. 